\title{
Influence of limnological zones on the spatial distribution of fish assemblages in three Brazilian reservoirs
}

\author{
Bárbara BECKER,,$^{*}$ Bárbara DE OLIVEIRA SANCHES GALHARDO,${ }^{1}$ Diego R. MACEDO,${ }^{2}$ Robert M. HUGHES, ${ }^{3}$ \\ Marcos CALLISTO, ${ }^{2}$ Gilmar B. SANTOS ${ }^{1}$
}

${ }^{1}$ Programa de Pós-Graduação em Biologia de Vertebrados, Pontifícia Universidade Católica de Minas Gerais, Avenida Dom José Gaspar, 500, 30.535-610, prédio 41, Belo Horizonte, MG, Brazil; ${ }^{2}$ Departamento de Biologia Geral, Instituto de Ciências Biológicas, Universidade Federal de Minas Gerais, 486, 30.161-970, Belo Horizonte, MG, Brazil; ${ }^{3}$ Amnis Opes Institute and Department of Fisheries and Wildlife, Oregon State University, 200 SW 35th Street, Corvallis, OR 97333, USA

*Corresponding author: barbara_becker@ymail.com

\begin{abstract}
Reservoirs can have both positive and negative effects on different fish species depending on the species concerned and reservoir morphology, flow regime, and basin location. We assessed the influence of limnological zones on the ichthyofauna of three large neotropical reservoirs in two different river basins. We sampled fish through use of gill nets set at 40 systematically selected sites on each reservoir. We used satellite images, algae, and suspended solids concentrations to classify those sites as lacustrine or riverine. We observed significant differences in assemblage composition between riverine and lacustrine zones of each reservoir. We tested if the same zone (lacustrine or riverine) showed the same patterns in different reservoirs. In São Simão, the riverine zone produced greater abundances of native species, long-distance migratory species, diversity, and richness, whereas the lacustrine zone supported greater total and nonnative species abundances. Conversely, in Três Marias, the riverine zone supported greater total and non-native species abundances, whereas the others traits evaluated did not differ significantly between zones. Only lacustrine sites occurred in Volta Grande Reservoir. The same zones in the three reservoirs usually had significantly different patterns in the traits evaluated. The differences in spatial patterns observed between reservoirs could be explained partly by the differing morphologies (complex versus simple), the differential influence on tributaries of each reservoir and basin positions (presence or absence of upstream dams) of the reservoirs.
\end{abstract}

Key words: Upper Paraná Basin; upper São Francisco Basin; fish assemblages; zonation; dam effects.

Received: May 2015. Accepted: September 2015.

\section{INTRODUCTION}

Changes in community composition, including local species extinctions and introductions, can occur rapidly as a consequence of human activities (Clavero and Hermoso, 2010; Mejía-Mojica et al., 2014). Large dams create major changes in rivers globally (Dynesius and Nilsson, 1994; Stanford et al., 1996; Hughes et al., 2005) and in Brazil, where there are more than 700 plants operating for power generation (Agostinho et al., 2008). The reservoirs behind dams create discontinuous longitudinal gradients because of changes in hydrology and geomorphology and consequently on the chemical and physical features of rivers (Oliveira et al., 2003; Britto and Carvalho, 2006; Terra et al., 2010).

Damming establishes physical barriers that limit fish movement (upstream and downstream), contributing to population isolation and extirpation ( Hughes et al., 2005; Araújo et al., 2008; Pompeu et al., 2012). Thus, loss of connectivity is another relevant issue related to river damming, and it is associated with degraded fish assemblage condition (Musil et al., 2012). Dams disrupt migration routes (Hoeinghaus et al., 2009) that are particularly important for fish species with long-distance migrations that depend on long river reaches for reproduction and growth. Many native species are not tolerant enough to become competitive in the new environment because lotic species are replaced by lentic species (Irz et al., 2002; Hughes et al., 2005; Sanches et al., 2016). As a result, the fish assemblage that once inhabited the river is substantially modified.

The dominance of non-native species in the new environment is another concern (Hoeinghaus et al., 2009) because reservoirs often shift from native-dominated stream fishes to non-native invasive-dominated fish assemblages (Clavero and Hermoso, 2010). This occurs because of intentional and accidental introductions of non-natives to support fisheries and to help control pest organisms, plus the greater environmental tolerances to anthropogenic disturbance of the introduced species (Moyle and Light, 1996; Hughes et al., 2005; Terra et al., 2010).

These impoundments combine ecological and functional features of both rivers and lakes, so it is possible to find distinct habitats that are more lake-like or river-like in the same reservoir (Søballe and Kimmel, 1987; Terra et al., 2010; Sanches et al., 2016). Usually, the upper part of a reservoir tends to have riverine features, whereas the 
lower part has lacustrine characteristics (Irz et al., 2002; Terra et al., 2010; Sanches et al., 2016). However, the presence of tributaries along the reservoir can reset these patterns somewhat (Sanches et al., 2016). Freshwater fish species respond differently to these riverine/lacustrine zones because the differing habitat types control the spatial distribution of fish species and the resulting fish assemblages (Holmgren and Appelberg, 2000; Irz et al., 2002; Terra et al., 2010). For example, riverine zones tend to support more native species (Oliveira et al., 2005; Agostinho et al., 2007; Gao et al., 2010) and rare species (Oliveira et al., 2003), whereas lacustrine zones tend to support fewer species (Oliveira et al. 2004; Agostinho et $a l ., 2007)$. If reservoir riverine and lacustrine zones support markedly different fish assemblages, it would be wise to manage them differently if managers desire to conserve or rehabilitate native fish assemblages and control invasive non-native species. For example, zones supporting healthy populations of native fish species or relatively large numbers of rare fish species could be designated as conservation or protection areas with improvements or actions focused at those locales (Hughes et al. 2005; Wang et al. 2006). On the other hand, zones or entire reservoirs supporting few native fish species or mostly tolerant or non-native fish species could be designated as rehabilitation areas and targeted for improvement projects at local and catchment scales (Hughes et al. 2005; Mueller et al. 2005; Valdez and Muth 2005; Wang et al. 2006).

We sought to verify if distinct reservoir zones affected the fish assemblages of three large neotropical reservoirs in two differentbasins. We tested the hypotheses that i) spatial distribution of fish assemblages is influenced by reservoir zone; ii) fish species abundance and richness are greater in riverine zones; iii) the same zones from different reservoirs show similar patterns in the traits evaluated.

\section{METHODS}

\section{Study area}

The study region comprised the upper portion of two large neotropical Brazilian river basins: the Paraná and São Francisco. We sampled one reservoir in the São Francisco Basin: Três Marias (TM), and two reservoirs in the Paraná Basin: São Simão (SS) and Volta Grande (VG).

The Paraná River is $3965 \mathrm{~km}$ long, from its source in the Mantiqueira Range, to the La Plata River in Buenos Aires (Stevaux et al., 2009). It is the second longest river in South America, and is formed by the junction of the Grande and Paranaíba Rivers (Agostinho et al., 2008; Stevaux et al., 2009). The Upper Paraná River Basin is located upstream of the old Sete Quedas waterfalls (now flooded by Itaipu Reservoir) (Langeani et al., 2007). This region has the greatest number of large reservoirs in Brazil (over 145 ) with only $230 \mathrm{~km}$ of freely flowing reaches between
Porto Primavera and Itaipu Reservoirs (Agostinho et al., 2008). São Simão reservoir (geographical coordinates in UTM: 22K 551969E 7896233S) has a storage volume of 5.5 billion $\mathrm{m}^{3}$ of water and its maximum depth is $127 \mathrm{~m}$. It began operations in 1978 (CEMIG, 2014). Volta Grande reservoir (22K 789414E $7782805 \mathrm{~S}$ ) has a storage volume of 268 million $\mathrm{m}^{3}$ of water and is the only run-of-river reservoir sampled in this study. This kind of reservoir has a reduced flood area and does not accumulate water, showing no significant changes in water level. It is the smallest reservoir that we studied and its operation began in 1974.

The São Francisco River is 2900 km long and flows through 6 Brazilian states and three biomes: Mata Atlantica (Atlantic forest), Cerrado (Savannah), and Caatinga (xeric shrubland). Approximately $6250 \mathrm{~km}^{2}$ was flooded by three large hydroelectric reservoirs. Três Marias, finished in 1960, currently is the only dam built in the Upper São Francisco Basin. The reservoir is 150 $\mathrm{km}$ long (Godinho and Godinho, 2003), has a storage volume of 15.2 billion $\mathrm{m}^{3}$, and is over $60 \mathrm{~m}$ deep in its lower reaches. The reservoir locations, the locations of their samplings stations and their classifications into lacustrine and riverine zones are illustrated in Fig. 1.

\section{Division of reservoirs into lacustrine and riverine zones}

We initially classified Landsat $5 \mathrm{TM}$ images taken during the respective sampling periods of each reservoir to visually distinguish riverine and lacustrine zones. After acquisition and image geo-referencing, we performed atmospheric correction by the dark object subtraction method (Chavez Jr., 1988). Areas influenced by rivers have higher concentrations of suspended solids and algae (Wetzel, 2001). We used three spectral bands: green $(0.52$ to $0.60 \mathrm{~mm}$ ), red (from 0.63 to $0.69 \mathrm{~mm}$ ), and near infrared spectral bands $(0.76$ to $0.90 \mathrm{~mm})$ to detect those two zones (Jensen, 2006). First, we used an algorithm of automatic unsupervised classification, to discriminate the areas that have distinct spectral response. We used the algorithm "Iterative Self-Organizing Data Analysis Technique" (ISODATA; Ball and Hall, 1965), one of most commonly used automated methods in multispectral image classification. The algorithm identifies patterns in spectral response and creates arbitrary classes. After that classification, we identified the areas that were visually distinct, considering that riverine areas have a markedly different reflectance than the lacustrine areas because of greater levels of suspended sediment (Fig. 2). To corroborate this classification, we assessed the significance of differences in measurements of turbidity and algae (measured by pheophytin $a$ ) between lacustrine and riverine sites. For this purpose, we employed a Mann-Whitney test corrected by Bonferroni criteria (Zar, 2009). Our limnological data and the methodology used for the separation 
of the areas did not enable us to separate a transition zone clearly. For the Volta Grande Reservoir just the lacustrine area was identified.

Some authors have classified sites near the dam as lacustrine and those more distant as riverine (Petesse et al., 2007; Dabrowski et al., 2013). However, like Sanches et al. (2014) we observed riverine zones near the dam and lacustrine zones distant from the dam because of the relative influence of tributaries or deep flooded canyons, respectively. Therefore we used limnological characteristics to refine our initial remote sensing classifications to classify sites as riverine or lacustrine relative to their position to the dam as well as the relative influence of large tributaries near the dam and flooded canyons far from the dam.
Such a refined classification reflects both the riverscape concept (Fausch et al., 2002) and the river wave concept (Humphries et al., 2014), both of which reflect the pulsed nature of river-lake ecosystems, even in systems as large as the Laurentian Great Lakes (Regier et al., 2013).

\section{Fish sampling}

We collected fish between April and May in 2011 (Três Marias), 2012 (Volta Grande) and 2013 (São Simão). We sampled each reservoir at 40 littoral zone sites uniformly spread along its perimeter with a random start point. At each site, we set 10 gill nets, each 20 -m long and with mesh size varying from 3 to $16 \mathrm{~cm}$ (between opposing knots). Five pairs of nets were set in series at an angle
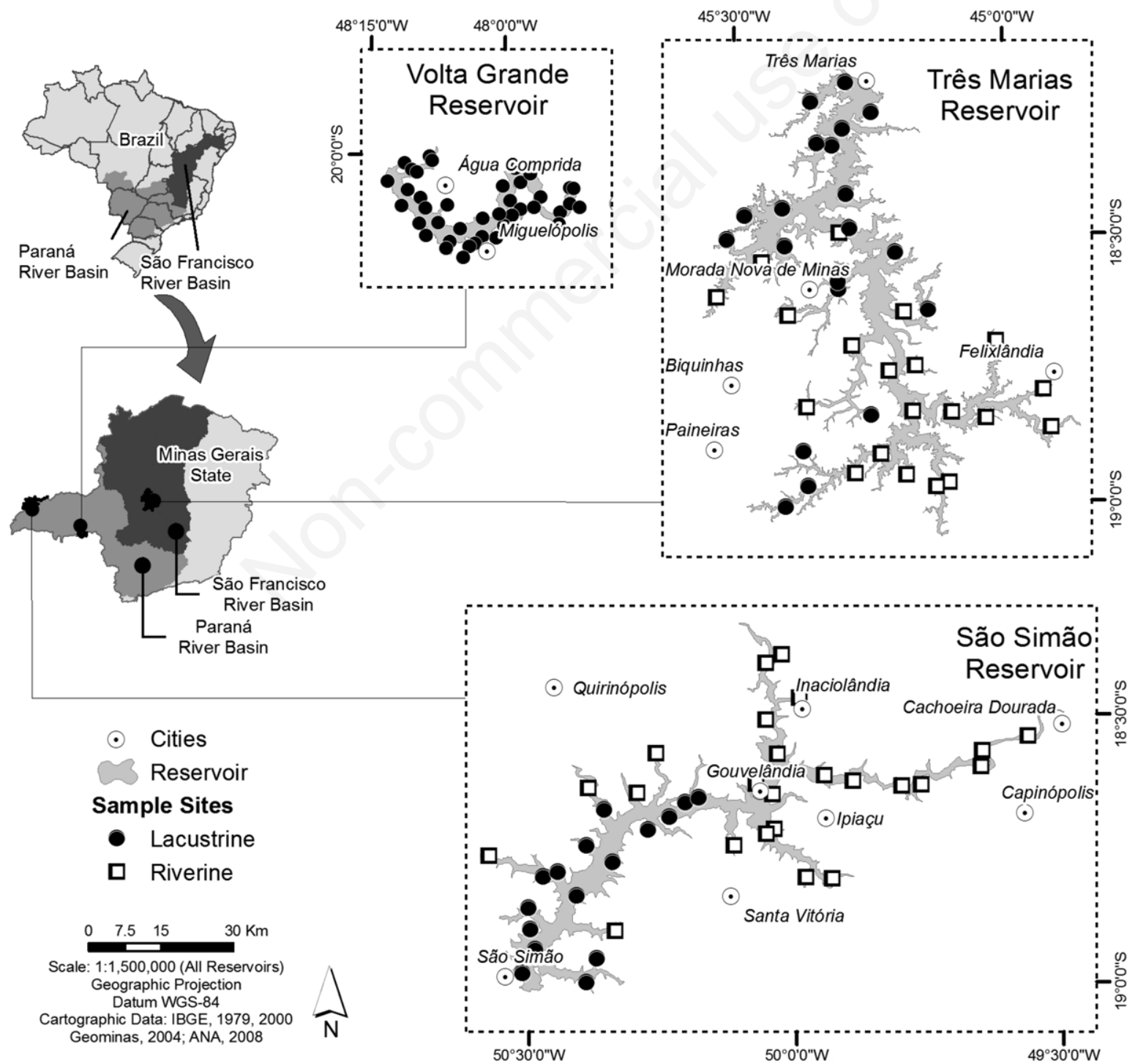

Fig. 1. Reservoir site locations and classifications into lacustrine and riverine zones (all Volta Grande sites were lacustrine). 
of approximately $45^{\circ}$ from the shore and with the smaller mesh nets nearest the shore. A distance of $40 \mathrm{~m}$ was maintained between each pair of nets, so the total site length was $200 \mathrm{~m}$. The nets were set in the evening and retrieved in the morning for a soak time of $15 \mathrm{~h}$.

The collected specimens were euthanized in clove oil solution with ethanol, following the guidelines of the CONCEA euthanasia practice (Brazilian National Council for Animal Experiments Control), fixed in 10\% formalin, and identified in the laboratory through use of taxonomic keys (Britski et al., 1988; Graça and Pavanelli, 2007). We considered as non-native those species that did not originally belong to the Upper Paraná or São Francisco Basins. We deposited voucher specimens in the ichthyological collections of the Museu de Ciências Naturais da Pontifícia Universidade Católica and Universidade Estadual do Paraná.

\section{Data analyses}

Abundance was determined by the sum of the number of collected fish per $100 \mathrm{~m}^{2}$ of gillnets, employed in 15 hours of operation. This procedure standardized catches and allowed quantitative catch comparisons. Data normality was verified through application of a KolmogorovSmirnoff test. The assemblage traits used to assess differences between lacustrine and riverine zones in the same

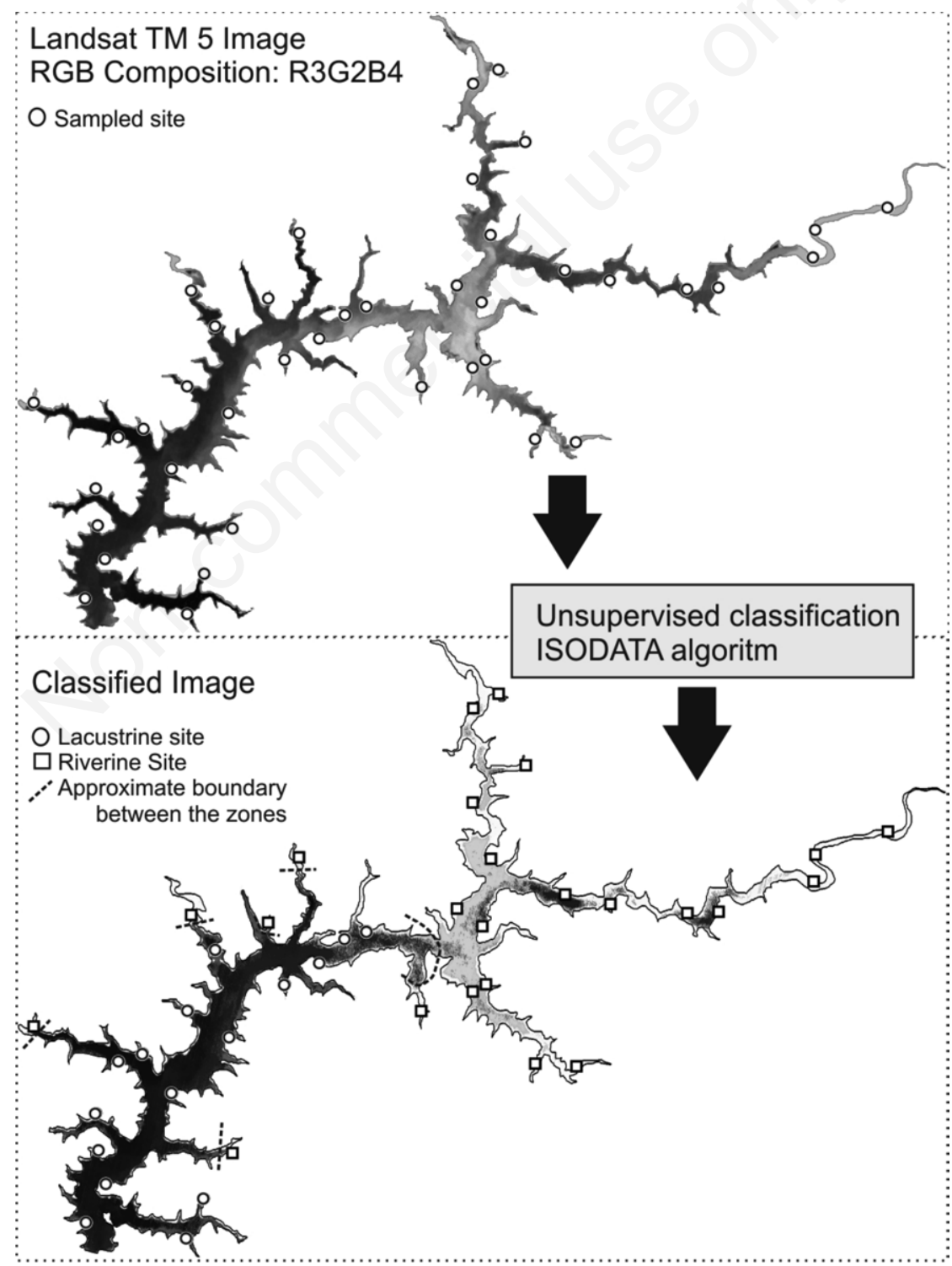

Fig. 2. Division of reservoirs into lacustrine and riverine zones using Landsat and the ISODATA algorithm. 
reservoir were: total abundance, abundance of long-distance migratory and non-native and native individuals, total species richness, and Shannon diversity $\left(\mathrm{H}^{\prime}\right)$ as stated in Magurran (2011). For the comparisons between the same zones in different reservoirs, we tested: $\%$ of migratory individuals, $\%$ of migratory species, $\%$ of native individuals, $\%$ of native species, evenness (Pielou's J'), total abundance, total species richness, and Shannon Diversity index (H'). To verify whether these differences were significant, we performed a Mann-Whitney test on non-parametric data (Zar, 2009). Because Volta Grande Reservoir was all lacustrine, only one zone could be evaluated.

Assemblage differences among reservoirs and between reservoirs zones were evaluated through use of nonmetric multidimensional scaling (NMDS) procedure from a BrayCurtis similarity matrix using 9999 iterations. For this analysis, species that occurred at $<5 \%$ of the sites were excluded to reduce analytical noise. After that, species abundance data were transformed by $\log (\mathrm{x}+1)$ (Legendre and Legendre, 1998; McCune et al., 2002). To validate the analysis, only stress values near 0.2 (Legendre and Legendre, 1998) were admitted. To test the significance of zonal clusters and reservoir assemblage differences, we performed PERMANOVA analyses (Bain et al., 1988; Manly, 1997).

A Mantel test was used to verify whether there was spatial autocorrelation on abundance data (Mantel, 1967). In that step we determined the correlation between a Bray Curtis similarity matrix constructed with abundance data and a Euclidean distance matrix constructed with geographic coordinates.

To determine the level of irregularity of the margins of each reservoir, we calculated its Shoreline Development Index (SDI) (Hutchinson, 1957) through use of the following equation:

Shore Line Development $(\mathrm{SDI})=$

$\mathrm{SL} \div 2 \cdot \operatorname{sqrt}(\pi \cdot \mathrm{Ao})$

where

SL, shoreline length;

sqrt, square root;

Ao, length of the circumference of a circle of area equal to that of the lake.

All the statistical analyses were conducted in Primer (Clarke and Gorley, 2006), Anderson et al., 2008; R (R Core Team, 2012) and Statistica 8.0 (StatSoft, Inc. 2007) softwares.

\section{RESULTS}

\section{Fish sampling}

We collected a total of 84 fish species, belonging to 19 families and 4 orders, in the three reservoirs (Supplementary Tab 1). Sixteen species were considered long-distance migratory and twelve were non-natives. São Simão had greater species richness (48 total, 11 migratory, 11 non-native), followed by Três Marias (37 total, 6 migratory, 3 nonnative) and Volta Grande (30 total, 4 migratory, 7 non-native). However, Três Marias Reservoir yielded many more individuals (3843) than São Simão Reservoir (2842) or Volta Grande Reservoir (1489).

Non-native species were important in all three reservoirs. In Três Marias, 2 non-native piscivorous species (Cichla cf. piquiti and Cichla kelberi) represented $20 \%$ of total abundance, mostly in the riverine zone. In São Simão, 3 non-native piscivorous species (Plagioscion squamosissimus, C. piquiti and Raphiodon vulpinus) were among the most abundant accounting for $32 \%$ of the individuals captured. In this reservoir the 11 non-native species captured occurred most frequently in the lacustrine zone. Of these, Geophagus proximus accounted for $33 \%$ of the total catch and P. squamosissimus and C. piquiti accounted for $27 \%$ of the total catch. Most of the catch and 8 of the species in Volta Grande consisted of non-native individuals; P. squamosissimus, Satanoperca cf. pappaterra, Metynnis gr. lippincottianus, C. piquiti, and C. kelberi, comprised $72 \%$ of the individuals collected (Supplementary Tab. 1).

\section{Effect of reservoir zone on fish assemblage abundance and richness}

We detected total abundance differences between reservoir zones in Três Marias and São Simão (Tab. 1). The riverine zone of São Simão yielded significantly more native individuals, migratory species individuals, species richness, and diversity than did the lacustrine zone. But only total and non-native abundances were significantly greater in the Três Marias lacustrine zone.

\section{Effect of reservoir zone on fish assemblage composition}

Ordination revealed differentiation among the fish assemblages in the different reservoir zones and river basins (Figs. 2 and 3). The fish assemblages captured in the lacustrine and riverine zones of São Simão are clearly distinguished (Fig. 2A) On the other hand, the fish assemblages in Três Marias are only weakly distinguished (Fig. 2B). The fish assemblages in São Simão and Volta Grande Reservoirs are more similar to each other (left side of Fig. 3) than to those in Três Marias because they are in the same river basin (Upper Paraná), whereas the Três Marias fish assemblages are in the São Francisco Basin. (Fig. 3b). Nonetheless, PERMANOVA results indicated significant differences in fish assemblage structure between riverine and lacustrine zones in both reservoirs (Três Marias: $\mathrm{t}=1.81, \mathrm{P}=0.003$; São Simão: $\mathrm{t}=1.99, \mathrm{P}=0.001$ ). NMDS plots (Fig. 4) and PERMANOVA results also in- 
dicate significant differences in fish assemblage structure among the three reservoirs $(\mathrm{t}=2.77 ; \mathrm{P}=0.001)$.

\section{Fish assemblage pattern similarity among different reservoirs}

When comparing the same zones among reservoirs, Três Marias and São Simão had non-significant differences in total abundance for both lacustrine $(\mathrm{U}=112.5$, $\mathrm{P}=0.1304)$ and riverine $(\mathrm{U}=239, \mathrm{P}=0.9811)$ zones because of the wide abundance ranges among sites (Fig. 5a). Both reservoirs had significantly fewer lacustrine zone individuals than Volta Grande (VG x TM: U=167, $\mathrm{P}=0.0002$; VG $x$ SS: $U=75, P<0.0001$; SS x TM:, $U=112.5, P=0.1305$ ). The three reservoirs differed significantly in lacustrine zone species richness (VG x TM: $\mathrm{U}=10, \mathrm{P}<0.0001$; VG x SS: $\mathrm{U}=118.5, \mathrm{P}<0.0001$; SS $\times \mathrm{TM}: \mathrm{U}=19, \mathrm{P}<0.0001)$ and diversity (VG $\times$ TM: $U=189, \mathrm{P}<0.0001$; VG $\times$ SS: $\mathrm{U}=171.5, \mathrm{P}=0.0070$; $\mathrm{SS} \times \mathrm{TM}: \mathrm{U}=15, \mathrm{P}<0.0001$ ), with the greatest richness and diversity in Três Marias (Fig. 5b,c). São Simão had significantly lower lacustrine evenness than Três Marias and Volta Grande (VG x SS: $\mathrm{P}=0.0044$, $\mathrm{U}=163$; TM $x$ SS: $\mathrm{P}<0.0001$, U=30; Fig 5d).

The lacustrine and riverine zones of Três Marias produced significantly greater percent of native species (lacustrine: VG x TM: $\mathrm{U}=1, \mathrm{P}<0.0001$; $\mathrm{SS} \times \mathrm{TM}$ : $\mathrm{U}=0$, $\mathrm{P}<0.0001$; riverine: $\mathrm{SS} \times \mathrm{TM}$ : $\mathrm{U}=65, \mathrm{P}<0.0001$; Fig.5e) and percent of native individuals (lacustrine: VG $\mathrm{T}$ TM: $\mathrm{U}=183, \mathrm{P}=0.0006$; $\mathrm{VG} \times \mathrm{SS}$ : $\mathrm{U}=152, \mathrm{P}=0.0023$; $\mathrm{SS} \times \mathrm{TM}$ : $\mathrm{U}=9, \mathrm{P}<0.0001$; riverine: $\mathrm{SS} \times \mathrm{TM}: \mathrm{U}=65, \mathrm{p}<0.0001$; Fig $5 \mathrm{f})$. The percent of migratory species individuals was significantly greater in São Simão lacustrine (VG x SS: $\mathrm{U}=385, \mathrm{P}=0.0281$; TM $x$ SS: $\mathrm{U}=53, \mathrm{P}<0.0001)$ and riverine (TM x SS: $\mathrm{U}=53, \mathrm{P}=0.0006$ ) zones (Fig. $5 \mathrm{~g}$ ). We found the same pattern for thepercentage of migratory species (lacustrine: VG x SS: $\mathrm{U}=123, \mathrm{P}=0.0002$; $\mathrm{TM} \times$ SS: $\mathrm{P}=0.0007, \mathrm{U}=54.5$; riverine: $\mathrm{TM} \times \mathrm{SS}: \mathrm{P}=0.0118$, $\mathrm{U}=133.5$; Fig. 5h). There was insignificant correlation be- tween the similarity matrix constructed from the abundance data and the dissimilarity matrix based on geographic coordinates (São Simão: $\mathrm{R}=-0.03, \mathrm{P}=0.51$; Três Marias: $\mathrm{R}=-0.08, \mathrm{P}=0.81$ and Volta Grande: $\mathrm{R}=0.08$, $\mathrm{P}=0.06$ ). The Shoreline Development Index (SDI) calculated for the three reservoirs showed that Três Marias was the most dendritic by far (SDI=1915), versus 968 for São Simão and 340 for Volta Grande.

\section{DISCUSSION}

\section{Fish sampling}

We found significant differences in the fish assemblages among the three reservoirs, although the assemblages in Volta Grande and São Simão Reservoirs are more similar to each other than to Três Marias (Fig. 4). This results from the fact that those two reservoirs are located in the same basin, and consequently, have several species in common (Supplementary Tab. 1). To better understand assemblage responses to differences in reservoir morphology, flow regime, and basin or ecoregion location it is necessary to implement more rigorous study designs of populations of reservoirs such as have been conducted by the U.S. Environmental Protection Agency in its National Lake Survey (Kaufmann et al., 2014a, 2014b).

\section{Effect of reservoir zone on fish assemblage abundance $\&$ richness}

The combination of spatial gradients and biological interactions can influence the distribution of different species with different ecological requirements and adaptability to one or more habitats (Gido et al., 2002; Field et al., 2009; Mouchet et al., 2013). The Três Marias riverine zone had greater total abundance of fishes than its lacustrine zone, which has been reported in other reservoir studies (Britto and Carvalho, 2006; Juza et al., 2009). Once these lakes are built, their fishes are likely to seek habitats that are

Tab. 1. Results of Mann-Whitney tests on fish assemblage traits between lacustrine and riverine zones.

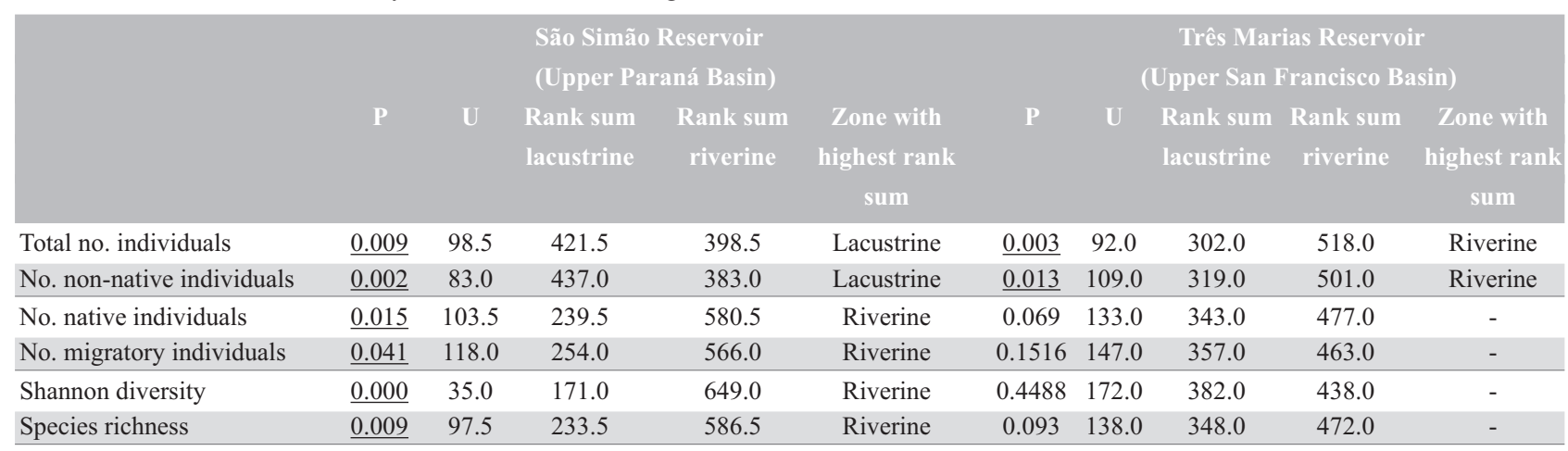

Underlined values indicate significant $P$-values $(P<0.05)$. 
most similar to their natural habitats, like tributary mouths (Fernando and Holčík, 1991; Sanches et al., 2014). Furthermore, the greater density of fishes in the riverine zone may reflect greater availability of resources there, compared with the lacustrine zone (Lind et al., 1993).

In São Simão Reservoir, however, the lacustrine zone supported more individuals than the riverine zone. One of the explanations for this is the high abundance of piscivorous species in this reservoir, which also was observed by Delariva et al. (2013) at Salto Caxias Reservoir. Visual predators are well adapted to lacustrine habitats with high transparency (Guthrie and Muntz, 1993). In addition to

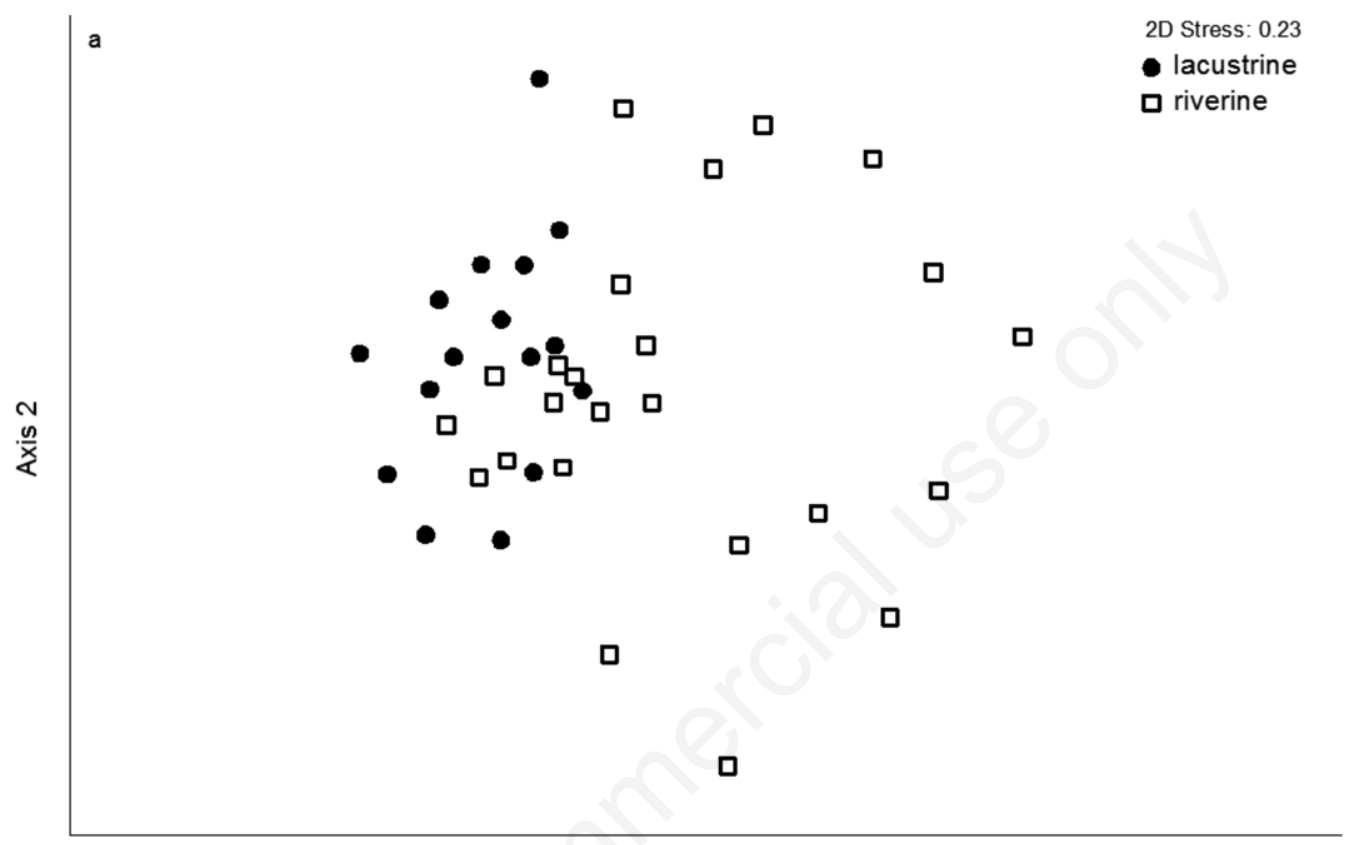

Axis 1

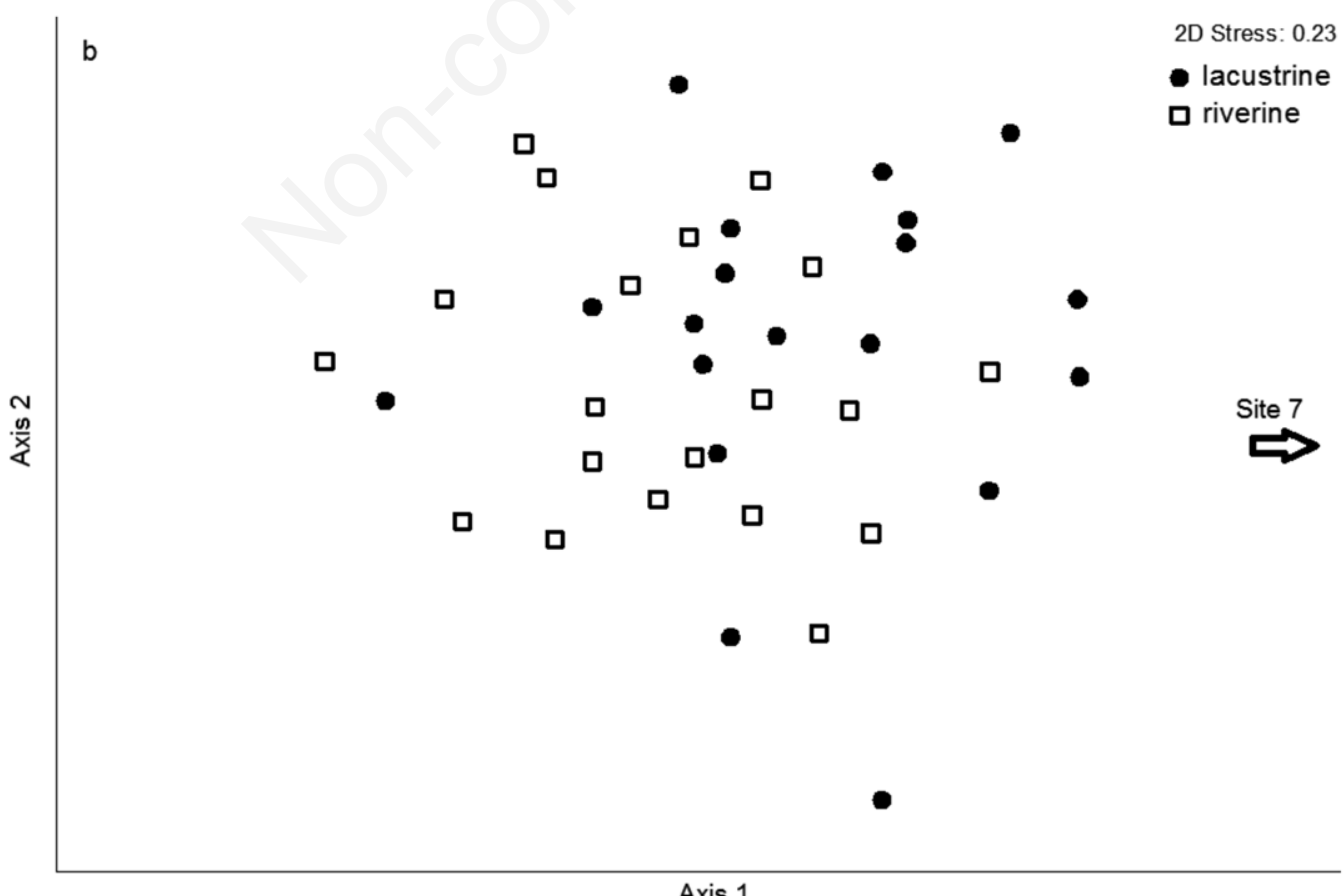

Axis 1

Fig 3. NMDS ordinations of fish species abundance data in a) São Simão and b) Três Marias Reservoirs by lacustrine and riverine zones. 
the high abundance of piscivores, the most frequently captured species in this reservoir (Geophagus proximus) was usually found in the lacustrine zone. Santos et al. (2010) found that a Geophagus species was also among the most abundant species in Funil Reservoir, southeastern Brazil. It exhibited restricted distribution to lacustrine sites, to which Geophagus species are well adapted. The success of this genus in reservoirs is partly explained by its detritivorous-iliophagous and omnivorous feeding habitats (Meschiatti, 1995), guilds that are often identified as prevalent in reservoirs (Agostinho et al., 2007).

\section{Effect of reservoir zone on fish assemblage composition}

We found that fish assemblage composition was affected by limnological zones in Três Marias and São Simão Reservoirs (Fig. 3), but there was only one zone in Volta Grande. This zonal influence was clear in São Simão, but less so in Três Marias Reservoir. Nevertheless the PERMANOVA analysis showed that fish assemblages in reservoir riverine zones differed significantly from those in their lacustrine zones in both reservoirs.

Areas influenced by tributaries have more organic mat- ter and suspended solids, providing temporary habitat for migratory species that use reservoirs as feeding areas $(\mathrm{Pa}-$ gioro and Thomaz, 2002; Oliveira et al., 2005; Miranda and Bettoli, 2010). That may explain the greater abundance of long-distance migratory individuals in the São Simão riverine zone. Okada et al. (2005) also found more migratory individuals in the Itaipu Reservoir riverine zone, as did Sanches et al. (2016) in Nova Ponte Reservoir.

The fish fauna of a freely flowing river constitutes the initial assemblage of the newly formed reservoir. Therefore, the remaining species are often concentrated in tributary mouths, which are more similar to the original habitat than other parts of the reservoir, where their ability to compete and survive is lower (Irz et al., 2002; Oliveira et al., 2004). We observed this pattern in São Simão, where the riverine zone had more native species than the lacustrine zone. Likewise, the lacustrine zone of this reservoir yielded more non-native individuals, mainly G. proximus and three piscivorous species. Environmental disruptions, such as reservoir construction, can contribute to the establishment of non-native species (Johnson et al., 2008; Daga and Gubiani 2012; Erős et al. 2012). Disturbed environments may compromise the competitive and survival abilities of native species, making them more

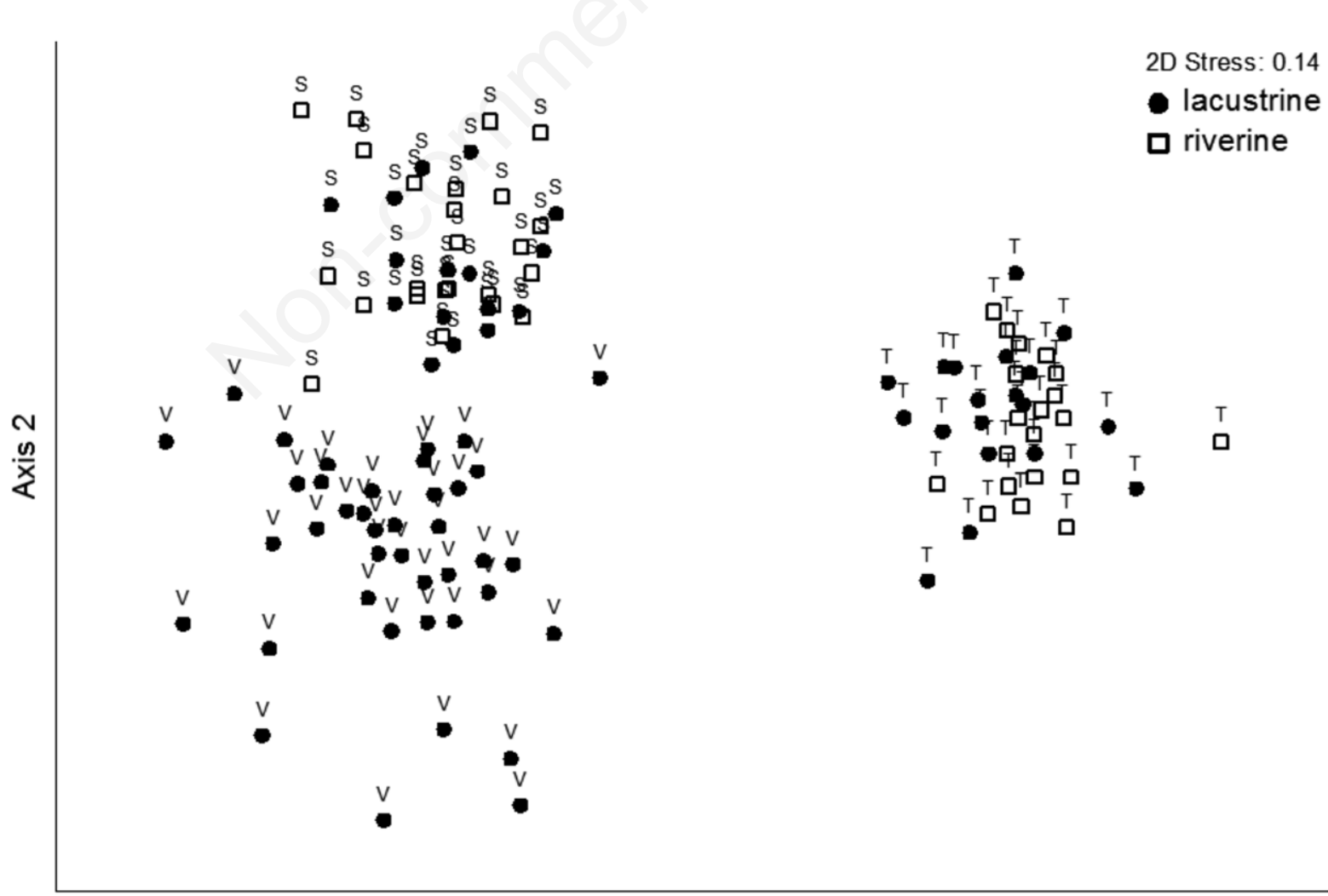

Axis 1

Fig. 4. NMDS ordinations depicting fish assemblage differences among São Simão (S), Três Marias (T), and Volta Grande (V) Reservoirs. 
vulnerable to invasive non-native species that are more tolerant of those altered environments (Moyle and Light, 1996). This pattern was observed by Sanches et. al. (2014) in Volta Grande Reservoir, where few native species were associated with abundant non-native piscivores (also see Supplementary Tab. 1). Piscivorous species were the most abundant among non-native species in Três Marias Reservoir. However, they were more abundant at riverine sites, where the total fish abundance was also higher. In Três Marias, increased prey density at riverine zone may have compensated the visual foraging constraints for the distribution of non-native predators, as observed by Jacobsen et al. (2014). According to this researcher, although predators be successful in high-visibility environments, predation rates may also be higher in places with lower visibility, but with high abundance of prey. Similar to São Simão, greater species richness has been reported in the riverine zone of other Brazilian reservoirs (Oliveira et al., 2004; Gubiani et al., 2010; Terra et al., 2010) as well as in reservoirs of other countries (Gido et al., 2002; Prchalová et al., 2009; Freedman et al., 2013). The riverine zone can be considered a quasi ecotone, because of the overlap of fluctuating riverine and lacustrine conditions (Terra et al., 2010). These environments have a wide range of exploitable microhabitats and high rates of primary productivity, which contribute to greater species richness and fish diversity than in other areas (Eadie and Keast, 1984; Cecílio et al., 1997; Irz et al., 2004; Oliveira et al., 2004). Furthermore, lacustrine zones often have chemical or thermal stratification creating microhabitats that are severe environmental filters for many species (Oliveira et al., 2003; Agostinho et al., 2008). Oliveira et al. (2004) found low richness in such microhabitats. Thus, environments that resemble the original riverine characteristics or those with greater habitat heterogeneity, such as tributary mouths, support more species with different ecological needs than other sites (Agostinho et al., 2007). There were no significant differences between lacustrine and riverine zones for some metrics in Três Marias. One factor that could explain those different patterns between reservoirs is their differing morphologies, because morphology influences water and sediment process dynamics, which also affect biological communities (Tundisi and Tundisi, 2008). Três Marias Reservoir has a pronounced dendritic pattern and complex morphology, which creates complex patterns in water circulation and accumulation of organic material and sediment (Tundisi and Tundisi, 2008) relative to São Simão and Volta Grande Reservoirs, which have simpler morphologies. Another difference between Três Marias, São Simão and Volta Grande Reservoirs is their locations. The latter two reservoirs are located in the Upper Paraná Basin, which has the highest dam concentration in Brazil (Agostinho et al., 2008). The cascade of reservoirs constitutes sediment and nutrients traps, reducing the concentrations of these elements in downstream reservoirs (Agostinho et al., 1995). Três Marias, on the other hand, is the only reservoir in the Upper São Francisco Basin; therefore, its sediment and nutrient deliveries are not influenced by upstream reservoirs and may be less limiting than in São Simão and Volta Grande.

\section{Fish assemblage pattern similarity among different reservoirs}

When comparing the same zones among different reservoirs, number of individuals was the only trait that did not differ significantly between São Simão and Três Marias, lacustrine or riverine zones. Differences in physical characteristics and location of these reservoirs are factors that may have influenced the lack of patterns of the evaluated traits,. although among-site abundance is a highly variable indicator as seen in Fig. 5a. Volta Grande, however, showed the lowest total abundance and richness. The low spatial heterogeneity in the lacustrine zone and the absence of a riverine zone may explain the low fish catch from this reservoir (Oliveira et al., 2003). Another possible explanation for the lower number of individuals and richness in Volta Grande is the P. squamosissimus dominance, a piscivorous species representing $44 \%$ of total captures in the reservoir (Sanches et al., 2014; Supplementary Tab. 1). This introduced species is well established in Volta Grande Reservoir, which lacks large tributaries and, therefore, lacks a riverine zone that can serve as a shelter for sensitive species. Predation by introduced piscivores is a well-established mechanism to limit or extirpate native prey (Miller et al., 1989; Moyle and Light 1996; Cucherousset and Olden 2011; Hughes and Herlihy 2012).

Três Marias and São Simão riverine zones had similar richness, diversity and evenness. Although they are in unconnected basins, the number of species and fish dominance patterns had the same response at sites with riverine influences. The same cannot be assumed for their lacustrine zones, because Três Marias had greater values than São Simão except for evenness. As discussed previously, São Simão is part of a series of reservoirs built on the Paranaíba River, which likely constitutes greater environmental pressure on fish assemblages than Três Marias, which is the uppermost reservoir of the São Francisco River.

The composition of migratory and native species differed among the three assemblages. Três Marias Reservoir supported the greatest percentage of native species and individuals, both in lacustrine and riverine zones, which is contrasted with the greater abundance and richness of non-native species collected in the other two reservoirs. Sanches et al. (2014) reported that in Três Marias 20\% of the total catch was non-native species, versus $78 \%$ in São Simão and 73\% in Volta Grande (Supplementary Tab. 1). 

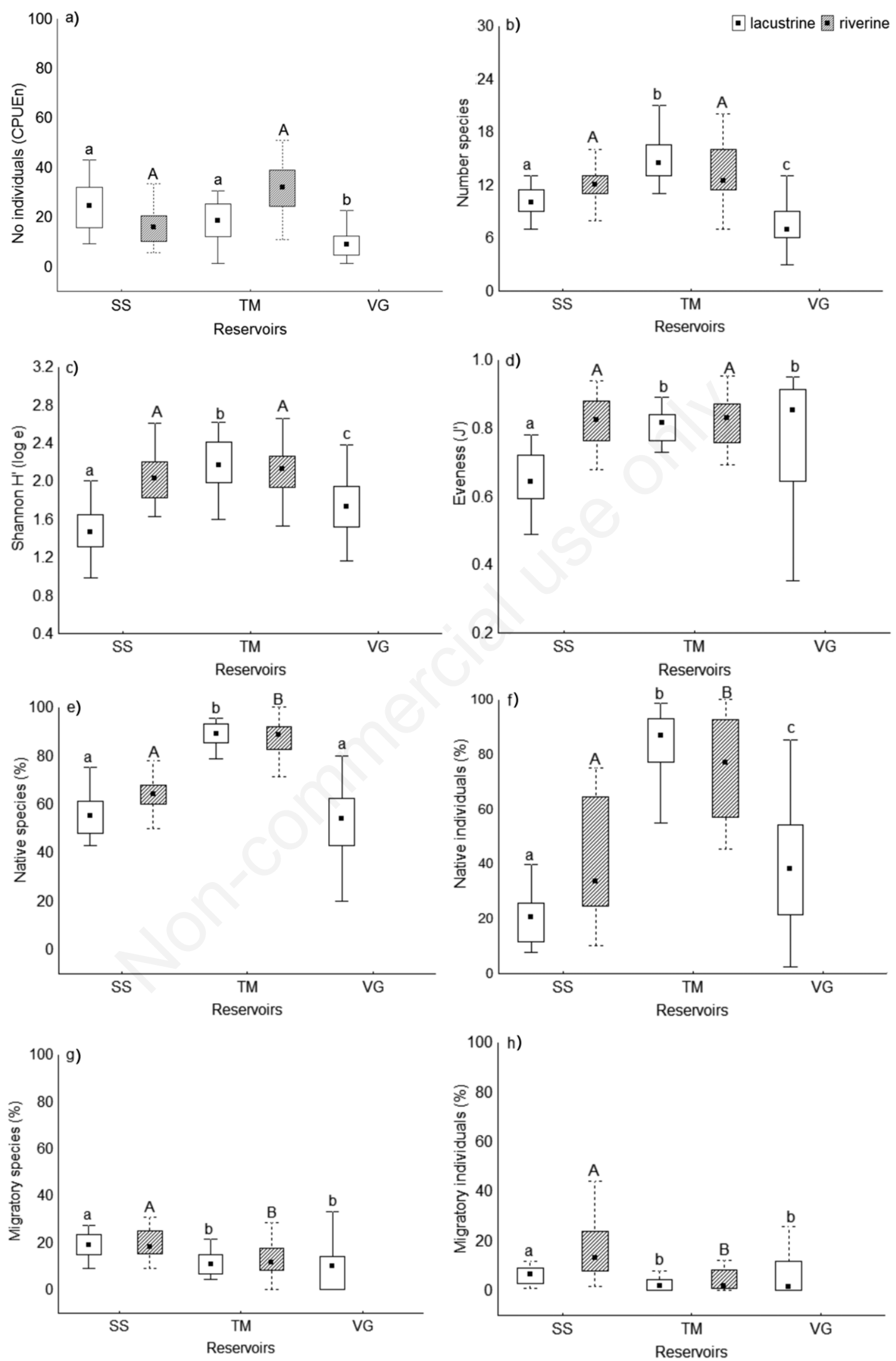

Fig. 5. Trait comparisons between the same zones of São Simão, Três Marias and Volta Grande Reservoirs. Boxes are: $25^{\text {th }}$ and $75^{\text {th }}$ percentiles, whiskers are non-outlier ranges, and dots are medians. Letter differences mean statistically significant differences among reservoirs. 
Despite belonging to the same basin as São Simão, Volta Grande had similar percentages of migratory individuals and species as Três Marias. Sanches et al., (2014) also found that Nova Ponte Reservoir had low migratory abundance and richness compared with São Simão. These differences are associated with the differential influence of tributaries in the three reservoirs evaluated, which provide temporary habitat for migratory species and can serve as a shelter for sensitive species.

Because of their differing effects on fish assemblages, we recommend that riverine and lacustrine zones of large reservoirs be managed differently if managers desire to conserve or rehabilitate native fish assemblages and control invasive non-native species. Keys to this management include normalizing flow regimes in riverine zones, limiting introductions and dispersal of non-native species, and limiting the number of other large dams and reservoirs in the river basin to the degree possible given other reservoir management objectives (Hughes et al., 2005)

\section{CONCLUSIONS}

Results confirmed our hypothesis that the composition of reservoir fish assemblages are affected by reservoir zonation. The lacustrine and riverine zones are occupied differentially depending on the ecological needs of fish species. However, we failed to confirm our hypotheses that fish species abundance, richness, diversity, and life history guilds are consistently greater in riverine zones or that the same zones from different reservoirs have similar responses for the traits evaluated. Depending on reservoir complexity and materials delivery, riverine zones may be refuges for remaining native and migratory species, reinforcing the importance of riverine habitats for conserving fish species in intensively dammed rivers. The river basins and morphologies of each reservoir also affected the evaluated traits, sometimes having greater influences on the assemblages than zonation. The effects of zonation patterns and tributary influences on fish assemblages could be assessed more effectively if sets of reservoirs with similar morphology, flow regime, and basin position were studied. This is true especially for those that are not located in a cascade of dams and which have stronger riverine characteristics (like Três Marias). Few studies consider reservoirs with such features; however, such research designs are essential for elucidating how fish assemblages behave in reservoirs with different and similar local and basin characteristics.

\section{ACKNOWLEDGMENTS}

We thank Centrais Energéticas de Minas Gerais (CEMIG) - Programa Peixe-Vivo, Companhia de Desenvolvimento dos Vales do São Francisco e do Parnaíba (CODEVASF), Fundação de Amparo à Pesquisa do Estado de Minas Gerais (FAPEMIG), and Conselho Na- cional de Desenvolvimento Científico e Tecnológico (CNPQ) for financial support. We also thank Tiago Pessali and Gilberto Salvador for the species identification. Marcos Callisto was awarded research productivity grant CNPq No. 302960/2011-2) and Minas Gerais researcher grant FAPEMIG (PPM-00077/13).

\section{REFERENCES}

Agostinho AA, Gomes LC, Pelicice FM, 2007.[ A ictiofauna de reservatórios], p. 69-97. In: Agostinho AA, Gomes LC, Pelicice FM (eds.), [Ecologia e Manejo de Recursos Pesqueiros em Reservatórios do Brasil].[Book in Portuguese]. Eduem, Maringá.

Agostinho AA, Pelicice FM, Gomes LC, 2008. Dams and the fish fauna of the Neotropical Region: impacts and management related to diversity and fisheries. Braz. J. Biol. 68:1119-1132.

Agostinho AA, Vazzoler AEAM, Thomaz SM, 1995. The high Paraná river basin: limnological and ichthyological aspects, p 59-104. In: J.G Tundisi, C.M Bicudo, T Matsumura Tundisi, (eds). Limnology in Brazil. ABC/SBL.

Anderson MJ, Gorley RN, Clarke KR, 2008. PERMANOVA+ for PRIMER: guide to Software and Statistical Methods. PRIMER-E, Plymouth: 214 pp.

Araújo FG, Pinto BCT, Teixeira TP, 2008. Longitudinal patterns of fish assemblages in a large tropical river in southeastern Brazil: evaluating environmental influences and some concepts in river ecology. Hydrobiologia 618:89-107.

Bain MR, Finn JT, Booke HE, 1988. Streamflow regulation and fish community structure. Ecology 69:382-392.

Ball GH, Hall DJ, 1965). Isodata: a method of data analysis and pattern classification. Technical Report. Information Sciences Branch, Office of Naval Research. Stanford Research Institute, Menlo Park.

Britski HA, Sato Y, Rosa ABS, 1988. [Manual de identificação de peixes da região de Três Marias - com chave de identificação para os peixes da bacia do São Francisco].[Book in Portuguese]. CODEVASF, Brasília: 115 pp.

Britto SGC, Carvalho ED, 2006. Ecological attributes of fish fauna in the Taquaruçu Reservoir, Paranapanema River (Upper Paraná, Brazil): composition and spatial distribution. Acta Limnol. Bras. 18:377-388.

Cecílio EB, Agostinho AA, Júlio-Jr HF, Pavanelli CS, 1997. [Colonização ictiofaunística do Reservatório de Itaipu e áreas adjacentes].[Article in Portuguese].Rev. Bras. Zool. 14:1-14.

CEMIG, 2014. Companhia Energética de Minas Gerais. Accessed: October 2014. Available from: www.cemig.com.br

Chavez Jr PS, 1988. An improved dark-object subtraction technique for atmospheric scattering correction of multispectral data. Remote Sens. Environ. 24:459-479.

Clarke KR, Gorley RN, 2006. Primer v6: user manual/tutorial. PRIMER-E, Plymouth: 115 pp.

Clavero M, Hermoso V, 2010. Reservoirs promote the taxonomic homogenization of fish communities within river basins. Biodivers. Conserv. 20:41-57.

Cucherousset J, Olden JD, 2011. Ecological impacts of non-native freshwater fishes. Fisheries 36:215-230.

Dabrowski J, Oberholster PJ, Dabrowski JM, Le Brasseur J, 
Gieskes J, 2013. Chemical characteristics and limnology of Loskop Dam on the Olifants River (South Africa), in light of recent fish and crocodile mortalities. Water SA 39:675-686.

Daga VS, Gubiani ÉA, 2012. Variations in the endemic fish assemblage of a global freshwater ecoregion: associations with introduced species in cascading reservoirs. Acta Oecologica 41:95-105.

Delariva RL, Hahn NS, Kashiwaqui EAL, 2013. Diet and trophic structure of the fish fauna in a subtropical ecosystem: impoundment effects. Neotrop. Ichthyol. 11:891-904.

Dynesius M, Nilsson C, 1994. Fragmentation and flow regulation of river systems in the northern third of the world. Science 266:753-762.

Eadie JM, Keast A, 1984. Resource heterogeneity and fish species diversity in lakes. Can. J. Zool. 62:1689-1695.

Erős T, Sály P, Takács P, Specziár A, Bíró, P. 2012. Temporal variability in the spatial and environmental determinants of functional metacommunity organization - stream fish in a human-modified landscape. Freshwater Biol. 57:1914-1928.

Fausch KD, Torgersen CE, Baxter CV, Li HW, 2002. Landscapes to riverscapes: bridging the gap between research and conservation of stream fishes. BioScience 52:483-498.

Fernando CH, Holčík J, 1991. Fish in reservoirs. Int. Rev. Ges. Hydrobiol. 76:149-167.

Field R, Hawkins B, Cornell H, et al., 2009. Spatial speciesrichness gradients across scales: A meta-analysis. J. Biogeogr. 36:132-147.

Freedman JA, Lorson BD, Taylor RB, Carline RF, Stauffer Jr JR, 2013. River of the dammed: longitudinal changes in fish assemblages in response to dams. Hydrobiologia 727:19-33.

Gao X, Zeng Y, Wang J, Liu H, 2010. Immediate impacts of the second impoundment on fish communities in the Three Gorges Reservoir. Environ. Biol. Fish. 87:163-173.

Gido KB, Hargrave CW, Matthews WJ, Schnell GD, 2002. Structure of littoral-zone fish communities in relation to habitat, physical, and chemical gradients in a southern reservoir. Environ. Biol. Fish. 63:253-263.

Godinho AL, Godinho HP, 2003. [Breve visão do São Francisco], p. 15-23. In: H.P. Godinho and A.L. Godinho (eds), [Águas, peixes e pescadores do São Francisco das Minas Gerais].[Book in Portuguese]. PUC Minas.

Graça WJ, Pavanelli CS, 2007. [Peixes da planície de inundação do alto rio Paraná e áreas adjacentes].[Book in Portuguese]. Eduem, Maringá: 241 pp.

Gubiani ÉA, Gomes LC, Agostinho AA, Baumgartner G, 2010. Variations in fish assemblages in a tributary of the Upper Paraná river, Brazil : a comparison between pre and postParana closure phases of dams. River Res. Appl. 26:848-865.

Guthrie DM, Muntz WRA,1993. Role of vision in fish behaviour, p 89-121. In: T.P. Pitcher (ed.), Behaviour of teleost fishes. Chapman and Hall, London.

Hoeinghaus DJ, Agostinho AA, Gomes LC, Pelicice FM, Okada EK, Latini JD, Kashiwaqui EAL, Winemiller K, 2009. Effects of river impoundment on ecosystem services of large tropical rivers: embodied energy and market value of artisanal fisheries. Conserv. Biol. 23:1222-1231.

Holmgren K, Appelberg M, 2000. Size structure of benthic freshwater fish communities in relation to environmental gradients. J. Fish Biol. 57:1312-1330.

Hughes RM, Herlihy AT, 2012. Patterns in catch per unit effort of native prey fish and alien piscivorous fish in 7 Pacific Northwest USA rivers. Fisheries 37:201-211.

Hughes RM, Rinne JN, Calamusso B, 2005. Historical changes in large river fish assemblages of the Americas: a synthesis. In: J.N. Rinne, R.M. Hughes and B. Calamusso (eds.), Historical changes in large river fish assemblages of the Americas. American Fisheries Society Symposium 45:603-612.

Humphries P, Keckeis H, Finlayson B, 2014. The river wave concept: integrating river ecosystem models. BioScience 64:870-882.

Hutchinson GE, 1957. A treatise on limnology.1. J. Wiley \& Sons, New York: 1015 pp.

Irz P, Argillier C, Proteau J, 2004. Contribution of native and non-native species to fish communities in French reservoirs. Fish Manag. Ecol. 11:165_172.

Irz P, Laurent A, Messad S, 2002. Influence of site characteristics on fish community patterns in French reservoirs. Ecol. Freshw. Fish 123136.

Jacobsen L, Berg S, Baktoft H, Nilsson PA, Skov C, 2014. The effect of turbidity and prey fish density on consumption rates of piscivorous Eurasian perch Perca fluviatilis. J. Limnol. 73:187-190.

Jensen JR, 2006. Remote sensing of the environment: an Earth resource perspective. Prentice Hall, Englewood Cliffs: 608 pp.

Johnson PT, Olden JD, Vander Zanden MJ, 2008. Dam invaders : impoundments facilitate biological invasions into freshwaters. Front. Ecol. Environ. 6:357-363.

J Jůza T, Vašek M, Kubečka J, Sed'a J, Matěna J, Prchalová M, Peterka J, Říha M, Jarolím O, Tušer M, Kratochvíl M, Čech M, Draštík V, Frouzová J, Hohausová E, Žaloudík J, 2009. Pelagic underyearling communities in a canyon-shaped reservoir in late summer. J. Limnol. 68:304-314.

Kaufmann PR, Hughes RM, Whittier TR, Bryce SA, Paulsen SG, 2014a. Relevance of lake physical habitat assessment indices to fish and riparian birds. Lake Reserv. Manage. 30:177-191.

Kaufmann PR, Peck DV, Paulsen SG, Seeliger CW, Hughes RM, Whittier TR, Kamman NC, 2014b. Lakeshore and littoral physical habitat structure in a national lakes assessment. Lake Reserv. Manage. 30:192-215.

Langeani F, Oyakawa OT, Shibatta OA, Pavanelli CS, Casatti L, 2007. [Diversidade da ictiofauna do Alto Rio Paraná : composição atual e perspectivas futuras].[Article in Portuguese]. Biota Neotrop. 7:1-17.

Legendre L, Legendre P, 1998. Numerical ecology. Developments in Environmental Modelling, Elsevier, Amsterdam: 853 pp.

Lind OT, Terrell TT, Kimmel BL, 1993. Problems in reservoir trophic-state classification and implications for reservoir management, p 57-67. In: M. Straskraba, J.G. Tundisi and A. Duncan (eds.), Comparative reservoir limnology and water quality management. Springer, Dordrecht.

Magurran AE, 2011. Biological diversity: frontiers in measurement and assessment. Oxford University Press, Oxford: 345 pp.

Manly BFJ, 1997. Randomization, bootstrap and Monte Carlo methods in biology. Chapman and Hall, London: 454 pp.

Mantel NA, 1967. The detection of disease clustering and a generalized regression approach. Cancer Res. 27:209-220.

McCune B, Grace JB, Urban DL, 2002. PC-ORD: Multivariate Analysis of Ecological Data. MjM Software Design. Computer software. 
Mejía-Mojica H, Contreras-MacBeath T, Ruiz-Campos G, 2014. Relationship between environmental and geographic factors and the distribution of exotic fishes in tributaries of the Balsas River Basin, Mexico. Environ. Biol. Fish. 98:611-621.

Meschiatti AJ, 1995. [Alimentação da comunidade de peixes de uma lagoa marginal do rio Mogi-Guaçu, SP].[Article in Portuguese]. Acta Limnol. Brasil. 3:115-137.

Miller RR, Williams JD, Williams JE, 1989. Extinctions of North American fishes during the past century. Fisheries 14:22-38.

Miranda LE, Bettoli PW, 2010. Large reservoirs, p. 545-586. In: W. Hubert and M. Quist (eds.), Inland fisheries management in North America. 3. American Fisheries Society, Bethesda, MD.

Mouchet MA, Burns MD, Garcia AM, Vieira JP, Mouillot D, 2013. Invariant scaling relationship between functional dissimilarity and co $\square$ occurrence in fish assemblages of the Patos Lagoon estuary (Brazil): environmental filtering consistently overshadows competitive exclusion. Oikos 122:247-257.

Moyle PB, Light T, 1996. Biological invasions of fresh water: empirical rules and assembly theory. Biol. Cons. 78:149-161.

Mueller GA, Marsh PA, Minckley WL, 2005. A legacy of change: the Lower Colorado River, Arizona-CaliforniaNevada, USA, and Sonora-Baja California Norte, Mexico, p 139-156. In: J.N. Rinne, R.M. Hughes and B. Calamusso (eds.) Historical changes in large river fish assemblages of the Americas. American Fisheries Society, Bethesda, MD.

Musil J, Horký P, Slavík O, Zbořil A, Horká P, 2012. The response of the young of the year fish to river obstacles: functional and numerical linkages between dams, weirs, fish habitat guilds and biotic integrity across large spatial scale. Ecol. Indic. 23:634-640.

Okada EK, Agostinho AA, Gomes LC, 2005. Spatial and temporal gradients in artisanal fisheries of a large Neotropical reservoir, the Itaipu Reservoir, Brazil. Can. J. Fish Aquat. Sci. 62:714-724.

Oliveira EF, Goulart E, Minte-Vera CV, 2003. Patterns of dominance and rarity of fish assemblage along spatial gradients in the Itaipu Reservoir, Paraná, Brazil. Acta Sci. Biol. Sci. 25:71-78.

Oliveira EF, Goulart E, Minte-Vera CV, 2004. Fish diversity along spatial gradients in the Itaipu Reservoir, Paraná, Brazil. Braz. J. Biol. 64:447-58.

Oliveira EF, Minte-Vera CV, Goulart E, 2005. Structure of fish assemblages along spatial gradients in a deep subtropical reservoir (Itaipu Reservoir, Brazil-Paraguay border). Environ. Biol. Fish. 72:283-304.

Pagioro TA, Thomaz SM, 2002. Longitudinal patterns of sedimentation in a deep, monomictic subtropical reservoir (Itaipu, Brazil-Paraguay). Arch. Hydrobiol. 154:515-528.

Petesse ML, Petrere Jr M, Spigolon RJ, 2007. Adaptation of the reservoir fish assemblage index (RFAI) for assessing the Barra Bonita Reservoir (São Paulo, Brazil). River Res. Appl. 612:595-612.

Pompeu PS, Agostinho AA, Pelicice FM, 2012. Existing and fu- ture challenges: the concept of successful fish passage in South America. Riv. Res. Applic 28:504-512.

Prchalova M, Kubeka J, Cech M, Frouzova J, Drastık V, Hohausova E, Juza T, Kratochv1l M, Matena J, Peterka J, Rıha M, Tuser M, Vasek M, 2009. The effect of depth, distance from dam and habitat on spatial distribution of fish in an artificial reservoir. Ecol. Freshw. Fish 18:247-260.

R Core Team, 2012. R: A language and environment for statistical computing. Vienna: R Foundation for Statistical Computing.

Regier HA, Hughes RM, Gannon JE. 2013. The lake sturgeon as survivor and integrative indicator of changes in stressed aquatic ecosystems in the Laurentian Basin, p 27-57. In: D. Dempsey and N. Auer (eds.), The Great Lake Sturgeon. Michigan State University Press.

Sanches BO, Becker B, Gomes PLA, Hughes RM, Santos GB, 2014. Ichthyofauna of four CEMIG Reservoirs: assemblage characteristics and conservation perspectives, p. 181-207. In: Calisto M, Hughes RM, Lopes JM, de Castro MA (eds), Ecological Conditions in Hydropower Basins. Companhia Energética de Minas Gerais, Belo Horizonte, MG.

Sanches BO, Hughes RM, Macedo DR, Callisto M, Santos GB, 2016. Spatial variations in fish assemblage structure in a southeastern Brazilian reservoir. Braz. J. Biol. 76:185-193.

Santos ABI, Terra BDF, Araújo FG, 2010. Influence of the river flow on the structure of fish assemblage along the longitudinal gradient from river to reservoir. Zoologia 27:732-740.

Søballe DM, Kimmel BL, 1987. A large-scale comparison of factors influencing phytoplankton abundance in rivers, lakes, and impoundments. Ecology 68:1943-1954.

Stanford JA, Ward JV, Liss WJ, Frissell CA, Williams RN, Lichatowich JA, Coutant CC, 1996. A general protocol for restoration of regulated rivers. Regul. River. 12:391-413.

Stevaux JC, Martins DP, Meurer M, 2009. Changes in a large regulated tropical river: the Paraná River downstream from the Porto Primavera Dam, Brazil. Geomorphology 113:230-238.

Terra BDF, Braz A, Araújo FG, 2010. Fish assemblage in a dammed tropical river: an analysis along the longitudinal and temporal gradients from river to reservoir. Neotrop. Ichthyol. 8:599-606.

Tundisi JG, Tundisi TM, 2008.[ Limnologia].[Book in Portuguese]. Oficina de textos, São Paulo: 631 pp.

Valdez BA, Muth RT, 2005. Ecology and conservation of native fishes in the Upper Colorado River Basin, p. 157-204. In: J.N. Rinne, R.M. Hughes, B. Calamusso (eds.), Historical changes in large river fish assemblages of the Americas. American Fisheries Society, Bethesda, MD.

Wang L, Seelbach PW, Lyons J. 2006. Effects of levels of human disturbance on the influence of catchment, riparian, and reach-scale factors on fish assemblages, p. 199-219. In: R.M. Hughes, L. Wang and P.W. Seelbach (eds.), Landscape influences on stream habitats and biological assemblages. American Fisheries Society, Bethesda, MD.

Wetzel RG, 2001. Limnology: lake and river ecosystems. Academic Press, San Diego: 998 pp.

Zar JH, 2009. Biostatistical Analysis. Prentice Hall, Englewood Cliffs: 960 pp. 